\title{
Book exchange in Azerbaijan in Middle Ages
}

\author{
A.Aliyeva-Kangarli1 \\ N.Kh.Babakhanova ${ }^{2 *}$ \\ J.A.Jafarov ${ }^{3}$ \\ ${ }^{1}$ Professor, ${ }^{2} \mathrm{PhD}$ candidate, ${ }^{3} \mathrm{PhD}$. Institute of Manuscripts, Azerbaijan \\ *Corresponding author: nbabakhanova@gmail.com
}

\section{Doi:10.5901/mjss.2015.v6n3s1p110}

\begin{abstract}
History of book exchange held in Azerbaijan in Middle Ages was looked through in the article. Libraries of mosques and Muslim religious schools as well as intellectuals played a big role in wide dissemination of library culture in Azerbaijan during this period. The article allows analyzing the works carried out in the field of book exchange by those libraries and intellectuals from library science and historiographical viewpoint.
\end{abstract}

Keywords: book exchange, Azerbaijan, Middle Ages, old libraries.

\section{Introduction}

Bringing books to Azerbaijan or transportation occurred in the period before VII century. It is obvious that 52 letters Albanian alphabet was compiled in Caucasian Albania in $\mathrm{V}$ century and a number of books were translated in the Albanian language and spread.

Works of literature of different peoples translated into the Albanian language were collected in the small libraries of that churches and schools. At the same time either the original or copy of works written in the Albanian language was recopied and taken to other countries and kept in different libraries.

It should me mentioned that widespread dissemination of the library culture in Azerbaijan, formation and enrichment of the libraries in the mosques and madrasas took place after spreading of Islam.

\section{Historical View}

Since the XI century a number of libraries were established in Azerbaijan on the initiative of a number of prominent persons for preservation of valuable works. One of these books was owned by the philosopher Abdulhasan Bahmanyar (993-1066). There were hundreds of books as well as books such as "Educational Book", "Logic of the book of splendor", The book of beauty and happiness", "The theme of the science of metaphysics", "Treatise on stages of reality" authored by the philosopher. When he was still alive, the "Educational Book" brought fame to the author not only in Azerbaijan but also outside the country, also copied and translated in Arabic and Persian languages, spread over a wide area. It testifies the existence of exchange of such works in Azerbaijan as a germ at that time. It can be assumed that, during that period the book exchange was carried out mainly by merchants. Because, a valuable work or book were considered to be precious commodity at that time.

Khatib Tabrizi (1030-1109) played a very significant role in the formation of book culture as well as book exchange. Kh. Tabrizi ran a rich personal library in Tabriz and donated as well as received books from a number of scholars. Azerbaijani scholar Abu Mansur Mahammad Al-Azhari (895-980) contacted with one of his pursuers, the Arabian philosopher Abul-Ula-Muarri (973-1057) and exchanged the books. Historically it is known that, KH. Tabrizi had taken as a gift 17 books from own library when going to the Arab scholar A. Muarri. After death of A.Muarri, an exhibition from those books (17 titles) and all of his works was arranged in Baghdad.

Referring to the work "Majmaul Buldan" by Yagut Hamawi who visited Azerbaijan in the Middle Ages, Academician Ziya Bunyadov and Aziz Mirahmadov show that, in the XI-XII centuries the rich palace libraries operated in Ganja and Barda. The palace library called "Dar-al-kutub" headed by Khaddad ibn Bakran Abu-al-Fadl-an-Nakhchivani and other books were established in Ganja. Nizami studier R.Aliyev writes that it was possible to find any book in the territory of 
Azerbaijan for reading. Library of "Dar-al-kutub" is considered to be a public library. "So, anyone who interested in was able to use the library (Bunyadov, 1973).

The researcher G.Kandli writes that in the XI century, rich palace libraries also existed in Ganja and Barda. These libraries had a very rich and rare book library fund. Ganja and Barda were great cultural and commercial centres and therefore merchants coming from different countries mentioned that there was a great demand for the book. Almost a significant portion of those books were brought through the merchants. In addition, in his work titled "The way of development of Azerbaian book", bibliographer scientist I.Zakiyev wrote that more than 20 books were kept in Ganja and Barda libraries.

Historical facts show that during the reign of Atabeys a great palace library (book house) found fame in Ganja as the richest library with unique book fund.

During their reign, Atabeys who paid special care to the cultural development also focused attention to the development of the library and enrichment of its fund. This book obtained the most valuable manuscripts from all the Eastern countries. Nasraddin Tusi (1201-1274) also played a great role in preservation of the book heritage in Azerbaijan and delivery to the future generations and their exchange. While being in prison in Alamug castle in the north of the city of Qazvin Tusi worked as the director of the library, which was established by Hasan Sabbah. By order of Hulaki khan Tusi was released from jail in 1256. After finding out that Tusi was of Turkic origin Hulaki khan appointed Tusi as his chief advisor.

After that Tusi had arranged a library in the Maragha observatory built by order of Hulaki khan and had collected here from around the world over four hundred thousand books. A large part of these books was collected from Baghdad, Damascus, Algeria, Mosul and other cities.

When speaking about the development of book culture in the middle ages, recopying process of manuscript books, their exchange, the prominent researcher, professor of history of the Azerbaijan library work A.Khalafov pays special attention to Fazlullah Reshidaddin (1247-1318). Professor notes that Reshidaddin led two libraries located in the northwest of Tabriz as well as the university and one library. Due to the hard work of Fazlullah Reshidaddin many valuable books werebrought from Iran, India, Egypt, China, Greece, Byzantine to both libraries with over sixty thousand books as well as to the library of the first university of Azerbaijan "Reshidiyya" University and instead of this the other works were copied out and sent. From history we know that in order to protect the book wealth and to exchange the books Reshidaddin used to make several times duplicates of books that he deemed as important through calligraphers under his subordination (Khalafov, 2007; Aliyeva-Kangarli, 2007).

In order to protect the book wealth Reshidaddin used to make several times duplicates of books that he deemed as important through calligraphers under his subordination and sent to other libraries of country, that treasure of the people would not lost at natural disasters. We must reiterate that his main purpose was to protect the library sources during natural disasters and reproduce the copies of works to be sent to the libraries of the other countries.

Researches show that among the personal, madrasa, mosque and palace libraries existed in the XI-XVI centuries the latter took an active part in the field of book exchange. P.Kazimi who studied the library work in Azerbaijan in the period Safavids, notes that among palace libraries Tabriz palace library established by the well-known public figure in XIV century Shah Ismail Khatai played an important role.

In 1522, Shah Ismail Khatai signed a state decree on the library work and allowed to collect the books by exchanging, purchasing and selling the book with different countries around the world.

Unlike Azerbaijan the book exchange in the Middle Ages in Western countries took place mainly between the church and clergies (Aliyeva-Kangarly, 2008). Sometimes, the monasteries who wished to get a book with the condition of giving back after reading it, sent the book as a pledge to another monastery of county where tat work existed and thus carried out the process reminding the international interlibrary subscription process in the modern sense. Missioners also played a special role in the exchange of books. After carrying out research in Vatican's secret archives in 2011, the historian scientist F.Alakbarli came to such a conclusion that the rulers of Ilkhanate, Atabeys, Ak Koyunlu, Kara Koyunlu, Safavids and Ghajar states exchanged documents and information, sent letters and books to Vatican, received response and books through the various missioners. This information was reflected in the missioners' report and other documents (Alakbarli, 2015). 


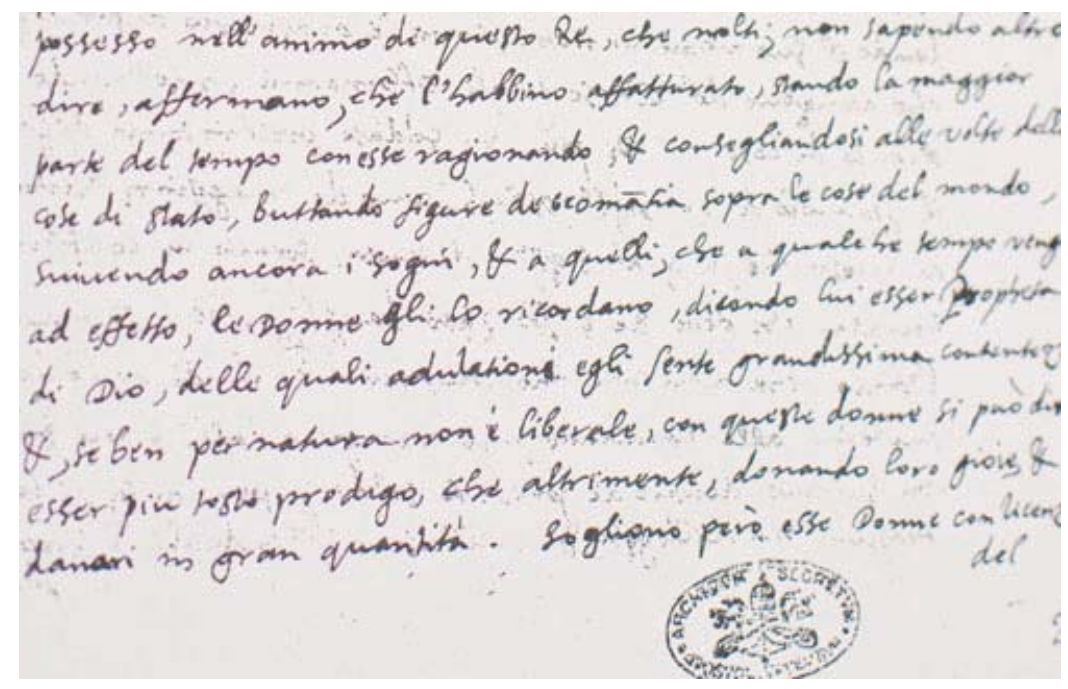

Figure 1. A piece of manuscript owned by the missioners visited Azerbaijan in the Middle Ages.

As a result of investigation conducted by the scientist it became known that in the Middle Ages the copies of many works were brought from Azerbaijan to the European countries and to Vatican. There are known and unknown manuscripts among those brought by the scientist from Vatican to Azerbaijan in digital information carrier. One of the manuscripts unknown to us is "Collection of Stories" written in the XV century in Turkish language. The mentioned Collection is one of the oldest samples of Azerbaijani literary language. Literary examples close to the language of "Dede Korkut" have been reflected. Besides, many unknown works of Shirvan scientists have been found in Vatican. The work by Mahmud Shirvani who lived in Turkey, the Ottoman Empire, a few medicine works by a physician from Shirvan who was called "Illagi" etc. have been detected.

Among the works of the known authors we can mention the work in mathematics written by Hingushah Nakhchivani, ancient manuscripts of Tabriz, Ardabil scientists, Zanjanies, famous person in Azerbaijan, Fuzuli, Shah Ismail Khatai. The copies detected by the scientist has not been found in our country till now.

\section{Conclusion}

As part of the research work by the historical-factografic methods we come to the conclusion that the history of book exchange in Azerbaijan is ancient and rich. According to the analyses of the materials we can say that the Azerbaijan territory played information hub role from the medieval. The book export and import were realized from western and eastern countries.

From the ancient times there were libraries with rich funds in Azerbaijan. The existing of the non-native (foreign) authors books in these libraries confirm that the book exchange was the content of the cultural relations in Azerbaijan. Nowdays Azerbaijan libraries have the international collaboration with the most of the world libraries and exercise book exchange. The main base of this activity compose of experience started from the medieval. The historical experience is very important for the development of the every operating area. We had brief glance on the book exchange in Azerbaijan in the middle ages in order to draw attention to the importance to studding of this experience.

\section{References}

Alakbarli, F.U. (2015). Azerbaijani manuscripts stored in Vatican. Baku: S\&E. Aliyeva-Kangarli, A. (2008). Azerbaijan folk-lore and book culture. Baku: Elm.

Aliyeva-Kangarli, A. (2011). National and spiritual values: creators and succesors. Baku: Progress. Bunyadov, Z. (1973). Azerbaijan in VII-IX centuries. Baku: Azerneshr.

Khalafov, A.A. (2007). The history of library work in Azerbaijan. Baku: Baku University Press. 